\title{
External Tufted Cells Drive the Output of Olfactory Bulb Glomeruli
}

\author{
Didier De Saint Jan, ${ }^{1,2,3}$ Daniela Hirnet, ${ }^{1,2,3}$ Gary L. Westbrook, ${ }^{4}$ and Serge Charpak ${ }^{1,2,3}$ \\ ${ }^{1}$ Institut National de la Santé et de la Recherche Médicale (INSERM) U603, ${ }^{2}$ Laboratory of Neurophysiology and New Microscopies, Université Paris \\ Descartes, and ${ }^{3}$ Centre National de la Recherche Scientifique (CNRS), UMR 8154, 75006 Paris, France, and ${ }^{4}$ Vollum Institute, Oregon Health and Science \\ University, Portland, Oregon 97239
}

\begin{abstract}
Odors synchronize the activity of olfactory bulb mitral cells that project to the same glomerulus. In vitro, a slow rhythmic excitation intrinsic to the glomerular network persists, even in the absence of afferent input. We show here that a subpopulation of juxtaglomerular cells, external tufted (ET) cells, may trigger this rhythmic activity. We used paired whole-cell recording and $\mathrm{Ca}^{2+}$ imaging in bulb slices from wild-type and transgenic mice expressing the fluorescent $\mathrm{Ca}^{2+}$ indicator protein GCaMP-2. Slow, periodic population bursts in mitral cells were synchronized with spontaneous discharges in ET cells. Moreover, activation of a single ET cell was sufficient to evoke population bursts in mitral cells within the same glomerulus. Stimulation of the olfactory nerve induced similar population bursts and activated ET cells at a lower threshold than mitral cells, suggesting that ET cells mediate feedforward excitation of mitral cells. We propose that ET cells act as essential drivers of glomerular output to the olfactory cortex.
\end{abstract}

Key words: olfactory bulb; glomerulus; external tufted cells; mitral cells; population synchrony; feedforward excitation

\section{Introduction}

Olfactory bulb glomeruli are the first site for odor processing in the brain. They contain synapses between axons of olfactory sensory neurons (OSNs), which bind odorants in the nasal epithelium, and mitral (M) cells, the output neurons of the bulb. A heterogenous mixture of juxtaglomerular cells surrounds the glomeruli and modulates the transfer of olfactory information to $\mathrm{M}$ cells (Aroniadou-Anderjaska et al., 2000; Ennis et al., 2001; McQuiston and Katz, 2001; Aungst et al., 2003; Hayar et al., 2004a; Murphy et al., 2005). Intraglomerular dendritic interactions between $\mathrm{M}$ and juxtaglomerular cells are likely to play important roles in shaping the representation of olfactory information, such as amplification of sensory input as well as synchronization and temporal patterning of M-cell activity (Wachowiak and Shipley, 2006).

Odors elicit fast and slow network oscillations in the bulb (Buonviso et al., 2006; Wilson and Mainen, 2006). The slow (2-8 $\mathrm{Hz}$ ) oscillations correlate with the respiratory cycle (Macrides and Chorover, 1972; Buonviso et al., 1992; Charpak et al., 2001;

\footnotetext{
Received Nov. 5, 2008; revised Jan. 5, 2009; accepted Jan. 9, 2009.

This work was supported by the Institut National de la Santé et de la Recherche Médicale, the Ministère de I'Education Nationale de la Recherche et de la Technologie [Actions Concertées Incitatives (ACI) Grant NIC0025 and Grant DRAB042492], the Centre National de la Recherche Scientifique, the Fondation pour la Recherche Médicale (Grant ICP20001222128), the Région lle de France (Sesame program), the Fondation Bettancourt Schueller, and the Human Frontier Science Program Organisation. We thank Thomas Knöpfel for the gift of EYFP and GCaMP-2 transgenic mice and members of the Charpak laboratory for support and suggestions during this project.

Correspondence should be addressed to Didier De Saint Jan or Serge Charpak, Institut National de la Santé et de la Recherche Médicale U603, Université Paris Descartes, Centre National de la Recherche Scientifique UMR 8154, 45 rue des Saints-Pères, 75006 Paris, France. E-mail: didier.desaintjan@univ-paris5.fr, serge.charpak@univ-paris5.fr.

D. Hirnet's present address: Intracelullar Calcium Dynamics, IZKF, Institute for Physiology I, Westfälische Wilhelms-Universität, Münster, Germany.

DOI:10.1523/JNEUROSCI.5317-08.2009

Copyright $\odot 2009$ Society for Neuroscience $\quad$ 0270-6474/09/292043-10\$15.00/0
}

Cang and Isaacson, 2003). Although the phasic nature of afferent inputs undoubtedly contributes to the slow patterning (Sobel and Tank, 1993), the intrinsic dynamics of the bulbar network could also be involved. Indeed, rhythmic activity can persist in the absence of nasal airflow (Fontanini et al., 2003) or be uncoupled from respirations (Grosmaitre et al., 2007). Moreover, M cells have the tendency to burst rhythmically within each glomerulus. For instance, increases in the excitability of the bulb network in isolated brain slices induce synchronized population bursts in $\mathrm{M}$ cells projecting to the same glomerulus (Isaacson, 1999; Carlson et al., 2000; Puopolo and Belluzzi, 2001; Schoppa and Westbrook, 2001; Christie et al., 2005), which have a time course similar to OSN-evoked M-cell responses (Carlson et al., 2000; De Saint Jan and Westbrook, 2007) and can be entrained by patterned afferent input (Schoppa and Westbrook, 2001).

Although the mechanism that drives the rhythmic activity of the glomerular network is at present unclear, external tufted (ET) cells, a population of juxtaglomerular cells, have recently received much attention (Hayar et al., 2004a,b, 2005; Antal et al., 2006; Zhou et al., 2006; Ma and Lowe, 2007; Liu and Shipley, 2008). These glutamatergic neurons fire bursts of action potentials (APs), receive monosynaptic inputs from olfactory neurons, and establish excitatory synaptic connections on periglomerular and short axon cells, two other types of juxtaglomerular neurons (Hayar et al., 2004a,b, 2005). The ET-cell pacemaker activity could thus propagate to the entire glomerular network.

We made pair recordings of ET and M cells in olfactory bulb slices from wild-type mice and imaged calcium transients in $\mathrm{M}$ cells from GCaMP-2 mice. Our results demonstrate that spontaneous population bursts in $\mathrm{M}$ cells are synchronized with the pacemaker activity of ET cells. More importantly, activation of single ET cells was sufficient to drive the activity of the M-cell 
assembly. ET cells were also more responsive than $\mathrm{M}$ cells to OSN input. We propose that sensory-evoked ET-cell activation mediates feedforward excitation of $\mathrm{M}$ cells.

\section{Materials and Methods}

Slice preparation. Experimental protocols were approved by Inserm health guidelines. Horizontal olfactory bulb slices were prepared from 14- to 30-d-old C57BL/6 mice or from F1 hybrids generated by crossing C57BL/6 and transgenic mice expressing the enhanced yellow fluorescent protein (EYFP) under the control of the Kv3.1 $\mathrm{K}^{+}$channel promoter (Metzger et al., 2002). These mice expressing EYFP in M cells were used to identify cells with an intact primary dendrite projecting in a glomerulus located not too deep in the slice. Results were similar in these two lines, which were thus collectively defined as wild-type mice. Slices from GCaMP-2 transgenic mice (Díez-García et al., 2005) were used for $\mathrm{Ca}^{2+}$ imaging experiments. These mice express a genetically encoded $\mathrm{Ca}^{2+}$ sensor also under the control of the Kv3.1 $\mathrm{K}^{+}$channel promoter. This results in expression of the $\mathrm{Ca}^{2+}$ probe in the same subset of bulb neurons. Mice were killed by decapitation, and the bulbs were rapidly dissected in ice-cold oxygenated $\left(95 \% \mathrm{O}_{2}-5 \% \mathrm{CO}_{2}\right)$ solution containing the following (in mM): $83 \mathrm{NaCl}, 26.2 \mathrm{NaHCO}_{3}, 1 \mathrm{NaH}_{2} \mathrm{PO}_{4}, 2.5 \mathrm{KCl}, 3.3$ $\mathrm{MgSO}_{4}, 0.5 \mathrm{CaCl}_{2}, 70$ sucrose, and 22 dextrose, $\mathrm{pH} 7.3$ (osmolarity 300 $\mathrm{mOsm} / \mathrm{L})$. Slices $(290-350 \mu \mathrm{m})$ were cut using a Leica VT1000S vibratome in the same solution, incubated for $30-40 \mathrm{~min}$ at $34^{\circ} \mathrm{C}$, and stored at room temperature in a standard extracellular solution until use. The extracellular solution contained the following (in mM): $125 \mathrm{NaCl}, 25$ $\mathrm{NaHCO}_{3}, 2.5 \mathrm{KCl}, 1.25 \mathrm{NaH}_{2} \mathrm{PO}_{4}, 1 \mathrm{MgCl}_{2}, 2 \mathrm{CaCl}_{2}$, and 25 dextrose (continuously bubbled with $95 \% \mathrm{O}_{2}-5 \% \mathrm{CO}_{2}$ ).

Electrophysiological recordings. Experiments were conducted at $30-$ $34^{\circ} \mathrm{C}$ on an upright microscope (Olympus BX51WI) with differential interference contrast optics. Patch pipette $(\sim 3-6 \mathrm{M} \Omega)$ contained the following (in mM): $135 \mathrm{~K}$-gluconate, $2 \mathrm{MgCl}_{2}, 0.025 \mathrm{CaCl}_{2}, 1 \mathrm{EGTA}, 4$ Na-ATP, $0.5 \mathrm{Na}-\mathrm{GTP}$, and 10 HEPES, pH $7.3(\sim 280 \mathrm{mOsm} / \mathrm{L})$. For studies of synaptic transmission, we added $10 \mathrm{~mm}$ glutamate in the internal solution of the presynaptic ET cell to avoid transmitter depletion (Ma and Lowe, 2007) and the resulting rundown of the postsynaptic M-cell response. For all voltage-clamp recordings, we replaced K-gluconate with $120 \mathrm{~mm}$ Cs- $\mathrm{MeSO}_{4}, 20 \mathrm{~mm}$ tetraethylammonium-Cl, and $5 \mathrm{~mm}$ 4-aminopyridine. Alexa-Fluor $488(10 \mu \mathrm{M})$ and Alexa-Fluor $594(5 \mu \mathrm{M})$ (Invitrogen) were routinely added to the internal solutions for $\mathrm{M}$ and ET cells, respectively, to visualize their glomerular projection. In some cases, biocytin $(10 \mathrm{~mm})$ was added to the intracellular solution.

For pair recording, an $\mathrm{M}$ cell or a displaced $\mathrm{M}$ cell (also known as tufted cells) was patched first, and its glomerulus was identified under fluorescence. An ET cell was then tentatively identified among juxtaglomerular cells in bright-field illumination based on its large, pear-shaped cell body with a thick apical dendrite (Hayar et al., 2004b). Additional physiological criteria were used to confirm its identity. ET cells had an input resistance of $125 \pm 70 \mathrm{M} \Omega(n=34)$. Some but not all ET cells spontaneously fired bursts of APs in cell-attached recordings. In wholecell current-clamp recordings, ET cells typically had a hyperpolarizationevoked depolarizing sag indicating the activation of $I_{\mathrm{h}}$ (Liu and Shipley, 2008) and most often responded to depolarizing current injections with a burst of APs, sometimes riding on the top of a $\mathrm{Ca}^{2+}$ spike (Hayar et al., 2004b; Antal et al., 2006; Liu and Shipley, 2008). Electrical coupling with an $\mathrm{M}$ cell was another criteria for identification of ET cells (see Results). Finally, the characteristic morphology of the ET cells (Hayar et al., 2004b; Antal et al., 2006) was confirmed under fluorescence at the end of each experiment or post hoc for cells filled with biocytin. For visualization of biocytin-filled cells, slices were fixed in $4 \%$ paraformaldehyde overnight, washed three times, and incubated in a permeabilizing solution containing cyanine 5 -conjugated streptavidin $(1 \mu \mathrm{g} / \mathrm{ml}$; Jackson ImmunoResearch) for $1 \mathrm{~d}$. After three wash cycles with PBS, sections were mounted. Labeled cells were visualized with a confocal microscope.

Recordings were made with a multiclamp 700A amplifier (Molecular Devices), filtered at $2-4 \mathrm{kHz}$, and digitized at $5-10 \mathrm{kHz}$ using Clampex 9 software (Molecular Devices). In voltage-clamp recordings, series resistance was compensated up to $70 \%$. For current-clamp recordings, a hy- perpolarizing current was injected to maintain neurons below AP threshold. We used the bridge balance function of the amplifier to compensate for access resistance. Olfactory sensory neurons were stimulated using a theta pipette filled with external solution and positioned in the olfactory nerve layer. The electrical stimulus $(100 \mu$ s, intensity of $10-100 \mu \mathrm{A})$ was delivered using an isolated stimulator (Digitimer).

Two-photon laser scanning $\mathrm{Ca}^{2+}$ imaging in GCaMP-2 mice. Fluorescence, reflecting changes in intracellular $\mathrm{Ca}^{2+}$, was imaged using a $63 \times$ water-immersion objective (Leica) with a custom-built two-photon laser scanning microscope (Charpak et al., 2001). The excitation wavelength was $900 \mathrm{~nm}$. We acquired images in frame mode (50-300 ms per frame). Acquisition and analysis were performed with custom-made software (Labview). Background fluorescence was obtained by averaging pixels from an unstained region. Normalized changes in fluorescence in percentage were calculated as $\Delta F / F=\left(F_{n}-F_{0}\right) \star 100 / F_{0}$, where $F_{n}$ is the background-corrected average intensity within a region of interest in frame $n$, and $F_{0}$ is the background-corrected intensity averaged at the start of a sequence. $\mathrm{Ca}^{2+}$ signals were analyzed in a region of interest covering the entire neuropil of a glomerulus to provide the best signalto-noise ratio for spontaneous glomerular $\mathrm{Ca}^{2+}$ signals. In such conditions, GCaMP-2 $\mathrm{Ca}^{2+}$ signals from out-of-focus whole-cell recorded $\mathrm{M}$-cell dendrites were not detectable. However, when imaging was focused on a specific M-cell dendritic branchlet, long trains of action potentials (in contrast to single spikes) did trigger modest but measurable calcium signals. This reflects the low sensitivity of the GCaMP-2 probe and contrasts with experiments using Oregon Green BAPTA1 (Debarbieux et al., 2003).

Analysis. Data were analyzed using Axograph X (Axograph X Scientific Software). For analysis of EPSC kinetics, we averaged traces from 5 to 40 trials aligned relative to the presynaptic spike. The latency of the M-cell EPSC was defined as the time interval between the peak of the presynaptic AP and the onset of the EPSC. The latter was defined as the intercept of a linear fit of the rising phase of the EPSC and the baseline axis. Population bursts were automatically detected based on their slow time course. Evoked M-cell responses were considered as population bursts when their time course was similar to spontaneous population currents. To avoid confusion with spontaneous events, only pairs in which population bursts were evoked in $>50 \%$ of the trials were selected for analysis. We used Student's $t$ tests (two-tailed) for statistical comparison and expressed the results as mean $\pm \mathrm{SD}$.

Drugs. 6-Nitro-7-sulfamoylbenzo[f]quinoxaline-2,3-dione (NBQX), D-2amino-5-phosphonopentanoic acid (D-AP-5), and 2-(3-carboxypropyl)-3amino-6-(4 methoxyphenyl)pyridazinium bromide (gabazine) were purchased from Tocris Cookson or Ascent Scientific, and tetrodotoxin (TTX) was from Latoxan.

\section{Results}

\section{Glomerulus-specific population bursts in mitral cells}

In previous studies, slow rhythmic glomerulus-specific activity has been induced by removal of $\mathrm{Mg}^{2+}$ (Puopolo and Belluzzi, 2001), blockage of glutamate transporters (Isaacson, 1999; Christie et al., 2005) or $\mathrm{GABA}_{\mathrm{A}}$ receptors (Carlson et al., 2000; Puopolo and Belluzzi, 2001), or exogenous activation of NMDA receptors (Schoppa and Westbrook, 2001). We observed spontaneous rhythmic activity in most $\mathrm{M}$ cells in control conditions. In cell-attached recordings, barrages of APs at high frequency alternated with periods of relative silence $(n=7)$ (Fig. $1 A)$. In wholecell records, periodic barrages of IPSCs and EPSCs were superimposed on a long-lasting inward current (Fig. $1 A$ ) that occurred irregularly and at low frequency (range of 0.1-1.2 events/s). In some cells, spontaneous slow events were infrequent or difficult to detect because of unclamped outward IPSCs that partially masked slow inward currents. Blocking $\mathrm{GABA}_{\mathrm{A}}$ receptors with gabazine $(2 \mu \mathrm{M})$ facilitated slow rhythmic activity. Gabazine was thus routinely added to the extracellular solution to facilitate analysis of spontaneous events. However, in $\mathrm{M}$ cells with large slow inward currents under control conditions (as in the cell 
A
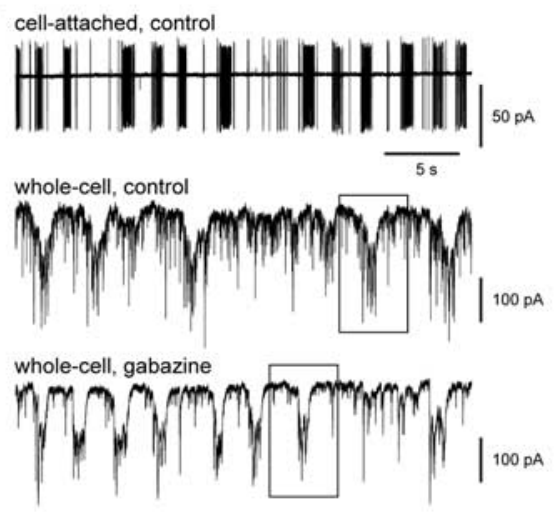

B

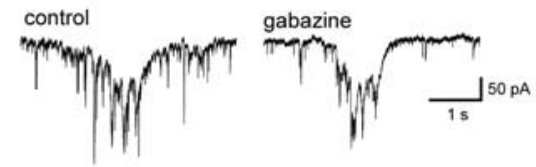

C
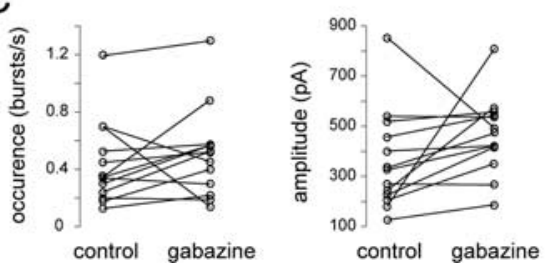

D
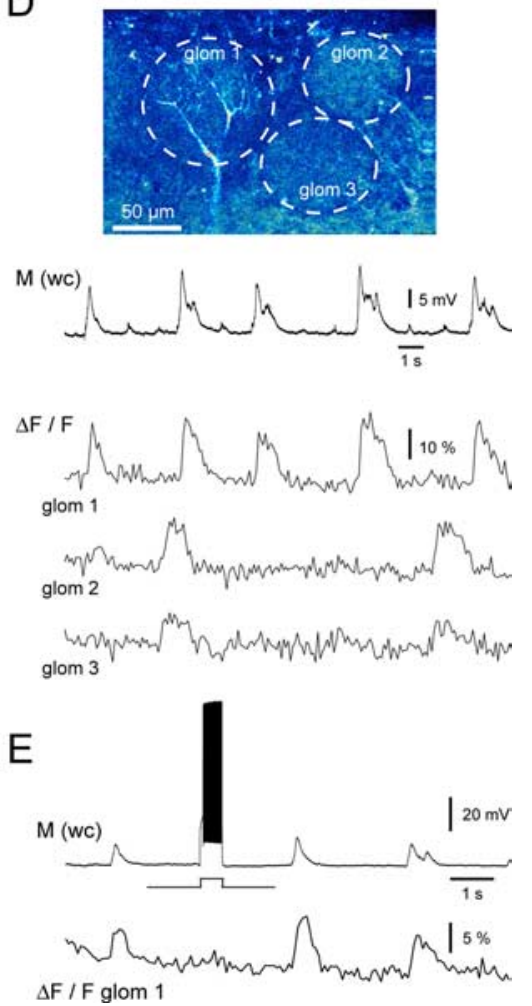

Figure 1. Electrical and optical detection of spontaneous population bursts in mitral cells. $\boldsymbol{A}$, Rhythmic firing of an $\mathrm{M}$ cell recorded in cell attached (top trace) in control conditions. In the whole-cell configuration, the same cell displayed periodic spontaneous slow currents in control conditions (middle) as well as in the presence of $2 \mu \mathrm{m}$ gabazine (bottom). $\boldsymbol{B}$, Individual population bursts delimited by boxes in $\boldsymbol{A}$ are shown at a faster timescale. Note the similar time course. $\boldsymbol{C}, 0$ ccurrence (left) and amplitude (right) of spontaneous population bursts under control conditions and in the presence of gabazine for 13 cells. $\boldsymbol{D}$, Spontaneous glomerular calcium signals in a slice from a GCaMP-2 mouse. Subthreshold depolarizations in a labeled M cell projecting its apical dendrite in glomerulus 1 (glom 1) were coincident with calcium increase $(\Delta F / F)$ in glomerulus 1 . Adjacent glomeruli (glom 2 and glom 3) were also spontaneously active and synchronized together but not with glom1. Region of interest for imaging analysis (dashed circle) covered the entire glomerulus. $\boldsymbol{E}$, Evoked discharge of an $\mathbf{M}$ cell (same as in $\boldsymbol{D}$ ) did not evoke any detectable calcium increase in glomerulus 1, unlike spontaneous population bursts in the recorded $M$ cell. Imaging experiments were done in the presence of $2 \mu \mathrm{m}$ gabazine. wc, Whole cell.

shown in Fig. 1A), gabazine did not significantly change the occurrence (control, $0.4 \pm 0.3 \mathrm{event} / \mathrm{s}$; gabazine, $0.5 \pm 0.3 \mathrm{event} / \mathrm{s}$; $n=13 ; p=0.5$ ) or the amplitude of individual events (control, $356 \pm 200$ pA; gabazine, $430 \pm 176 \mathrm{pA} ; n=13 ; p=0.2$ ) (Fig. $1 C$ ). Their time course was also similar in both conditions (Fig. $1 B$ ). Thus, block of fast synaptic inhibition is not critical to this rhythmic activity.

In the presence of gabazine, the long-lasting (one-third width, $423 \pm 168 \mathrm{~ms} ; n=13$ ) inward currents typically started with a small deflection lasting $\sim 50-100 \mathrm{~ms}$ that correlated in some cells with an increase in EPSC frequency (Figs. 1, 2). The buildup period was followed by a more explosive and faster component $(20-80 \%$ rise-time, $23.6 \pm 15 \mathrm{~ms} ; n=13)$. Some events lacked a buildup period. As shown previously (De Saint Jan and Westbrook, 2007), spontaneous slow currents reversed polarity at positive holding potentials and were blocked by AMPA and NMDA receptor antagonists (10 $\mu \mathrm{M}$ NBQX and $50 \mu \mathrm{M}$ D-AP-5, respectively) (data not shown). Also consistent with previous studies (Carlson et al., 2000; Puopolo and Belluzzi, 2001; Schoppa and Westbrook, 2001; De Saint Jan and Westbrook, 2007), spontaneous slow events were synchronized in cells projecting to the same glomerulus (see below) and thus were defined as population bursts.

The rhythmic activity was also examined in slices from
GCaMP-2 transgenic mice (Díez-García et al., 2005) that express a genetically encoded $\mathrm{Ca}^{2+}$ probe in $\mathrm{M}$ cells and in some JG cells (Chaigneau et al., 2007). In disinhibited slices from these animals, transient and uniform increases of fluorescence emanated from the neuropil of individual glomeruli (Fig. 1D). $\mathrm{Ca}^{2+}$ signals in individual $\mathrm{M}$-cell primary dendrites entering the glomerulus were sometimes seen in synchrony with the glomerular $\mathrm{Ca}^{2+}$ response. As illustrated in Figure $1 D$, optical signals in adjacent glomeruli were most often independent of each other (in five of six experiments), indicating that the mechanism underlying the optical signals was glomerulus specific. In simultaneous intracellular recording of $\mathrm{M}$ cell and imaging of its glomerulus, glomerular $\mathrm{Ca}^{2+}$ signals were coincident with subthreshold population bursts $(n=5)$. In contrast, dendritic calcium signals evoked by long suprathreshold depolarization (0.5-1 s long) of individual $\mathrm{M}$ cells were barely detectable when measured over the same region of interest $(n=4$; see Materials and Methods) (Fig. 1E). These results suggest that glomerular $\mathrm{Ca}^{2+}$ signals reflect activation of multiple $M$ cells synchronized during population bursts.

\section{Individual external tufted cells can evoke population bursts}

Our observations suggest so far that an excitatory network contained within a glomerulus drives population bursts in $\mathrm{M}$ cells. ET cells spontaneously and rhythmically fire bursts of APs in synchrony with other ET cells (Hayar et al., 2004b). We thus hypothesized that they might trigger population bursts in $\mathrm{M}$ cells. To test whether the pacemaker activity of ET cells was coordinated with population bursts in $\mathrm{M}$ cells, we made paired recordings of ET and M cells that projected to the same glomerulus. Spontaneous bursts of APs in ET cells, recorded in the cellattached mode, were coincident with slow population events in M cells $(n=15)$ (Figs. 2A, 3A). Specifically, $80 \%$ of spontaneous bursts in ET cells preceded the peak of a M-cell population burst by $10-80 \mathrm{~ms}$ ( $n=162$ events from 12 pairs) (Fig. $2 A$ ). When both cells were recorded in the whole-cell configuration, slow events with similar time course were synchronized (Fig. 2 B). In GCaMP-2 mice, glomerular $\mathrm{Ca}^{2+}$ signals were also coincident with burst of APs in ET cells recorded in cell attached $(n=40)$ (Fig. 2C) and with slow subthreshold depolarization in ET cells recorded in whole-cell current clamp $(n=20)$ (Fig. $2 D)$.

We next tested whether activation of an individual ET cell could trigger population bursts (Miles and Wong, 1983). Bursts of APs were evoked in individual ET cells by step depolarization (10-500 ms). In 18 of 43 cell pairs that had correlated spontaneous activity, an ET-cell discharge triggered a population burst in the $\mathrm{M}$ cell, i.e., a current with a slow time course similar to the spontaneous population burst (Fig. $3 B$ ). These evoked bursts were present in control conditions $(n=7)$ or in the presence of gabazine $(n=11)$. In contrast, evoked discharge in M cells failed 
A

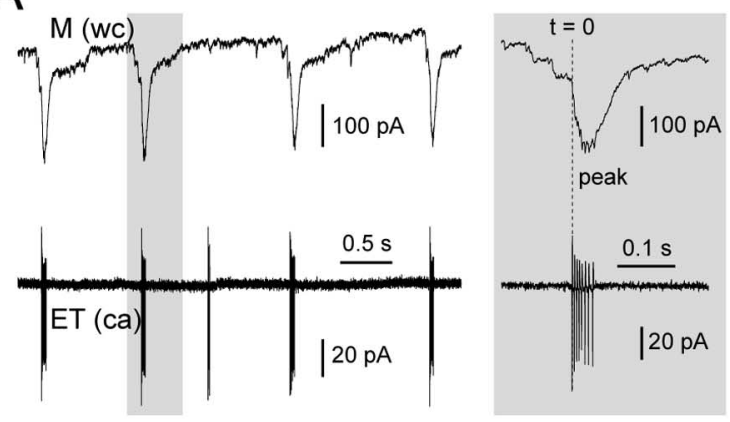

B

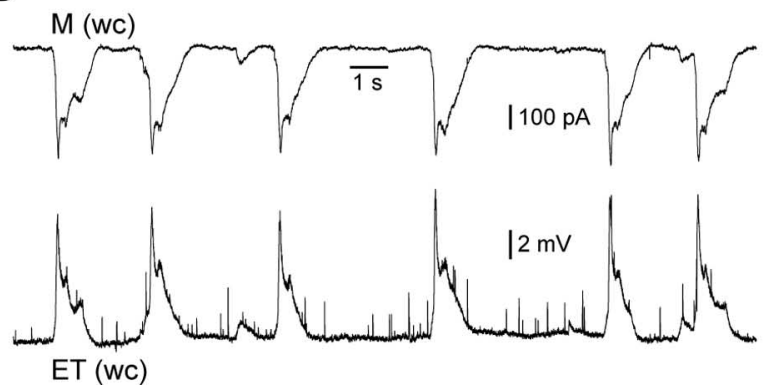

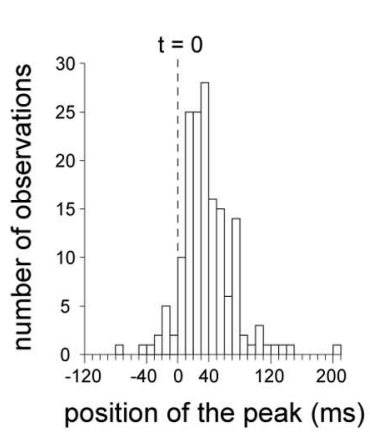

C
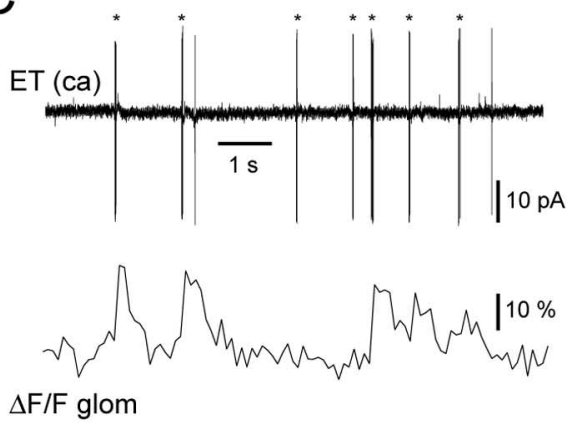

$\mathrm{D}$
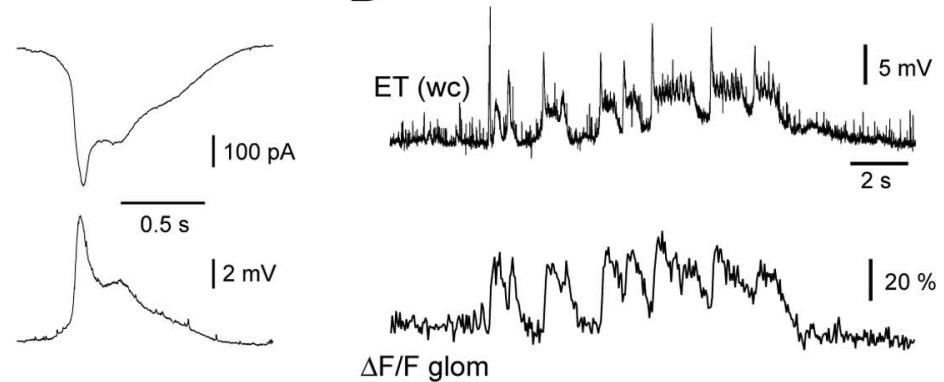

Figure 2. Correlated activity of mitral and ET cells. A, Paired recording of an M cell and an ET cell that projected to the same glomerulus. The M cell was recorded in the whole-cell configuration (top trace) and the ET cell in the cell-attached configuration (bottom trace). Population bursts in the M cell were synchronized with bursts of APs in the ET cell. Middle, Expanded currents delimited by the gray box. The position of the peak of each M-cell population burst was determined relative to the first AP of the synchronized burst in the ET cell ( $t=0 \mathrm{~ms})$ for constructing the histogram on the right (169 correlated events from 12 pairs). B, Correlated activity in an M cell (whole-cell voltage clamp, top trace) and an ET cell (whole-cell current clamp, bottom) simultaneously recorded. Right, Average trace calculated from eight aligned events. C, In slices from GCaMP-2 mice, most, but not all, bursts of spikes in an ET cell (asterisks in top trace, cell-attached recording) were correlated with $\mathrm{Ca}^{2+}$ signal in the glomerulus (glom) into which the cell projected. D. Correlated population bursts recorded in an ET cell and calcium signals imaged in its glomerulus. Experiments were all done in the presence of gabazine $(2 \mu \mathrm{m})$. ca, Cell attached; wc, whole cell.

to induce any response in ET cells $(n=12)$. ET cells are heterogeneous with respect to morphology and their firing patterns: some cells fire bursts of APs, whereas others show regular or irregular spiking (Antal et al., 2006). Consistent with this heterogeneity, depolarizing current injections evoked $\mathrm{Ca}^{2+}$ spikes in only a subset of ET cells ( 31 of 67). However, both types of ET cells could evoke population bursts in M cells (Fig. 3C,D). TTX (1 $\mu \mathrm{M})$ abolished spontaneous population bursts as well as evoked responses in M cells, whether the ET cell expressed $(n=4)$ (Fig. $3 C)$ or not $(n=4)($ Fig. $3 D) \mathrm{a} \mathrm{Ca}^{2+}$ spike. These data indicate that dendritic $\mathrm{Ca}^{2+}$ increases induced by $\mathrm{Ca}^{2+}$ spikes in ET cells (Zhou et al., 2006) are not sufficient to trigger population bursts in $\mathrm{M}$ cells.

\section{Electrical and chemical coupling of ET and M cells}

What mechanisms synchronize $\mathrm{M}$ and ET cells and might allow ET cells to drive a glomerular M cell ensemble? Electrical coupling through gap junctions mediates neural synchrony in many brain regions (Bennett and Zukin, 2004). In the bulb, M cells projecting to the same glomerulus are electrically coupled by connexin 36-mediated gap junctions (Schoppa and Westbrook, 2002; Christie et al., 2005). Electrical coupling also contributes to synchronization of ET cells (Hayar et al., 2005). To test for the presence of electrical synapses between $\mathrm{M}$ and ET cells, we injected a hyperpolarizing current (500 ms, 300-700 pA) alternatively in each cell. In every pair tested $(n=26)$, current injection in one cell elicited a small but unambiguous voltage deflection in the other cell (Fig. 4B), consistent with gap-junction-mediated electrical transmission. When the current was injected in the ET cell, the coupling coefficient was $1.4 \pm 1 \%$ (range of $0.3-3.6 \%$ )
(Fig. 4C). Electrical coupling was not accompanied by dye coupling when a single cell was loaded with biocytin or Alexa Fluor and was absent in cells projecting to different glomeruli $(n=5$; data not shown). Reciprocal coupling was observed in all cases (coupling coefficient from M to ET cell, $2.4 \pm 3.9 \%$; range of $0.3-6.1 ; n=25)$.

Chemical synaptic transmission is also a powerful means to drive and synchronize electrical activities in a neuron ensemble. Although there is (as yet) no ultrastructural evidence for synapses between these cells, individual APs in ET cells were time locked with excitatory synaptic currents in $\mathrm{M}$ cells during spontaneous activity $(n=6)$ (Fig. 5A). Moreover, population bursts evoked in $M$ cells by an ET-cell discharge were often preceded by a shortlatency EPSC time locked with the first AP in the ET cell (Fig. 3B). Individual APs evoked by brief depolarizing current steps in an ET cell also triggered NBQX-sensitive fast EPSPs in the $\mathrm{M}$ cell with an amplitude of $1.2 \pm 0.9 \mathrm{mV}(n=7)$ (Fig. $5 B)$. In voltageclamped M cells, the EPSC amplitude was $33 \pm 24 \mathrm{pA}\left(n=17 ; V_{\mathrm{h}}\right.$ $=-70 \mathrm{mV}$; range of $4-100 \mathrm{pA}$ ), with a $20-80 \%$ rise time of $2.1 \pm 0.3 \mathrm{~ms}$ and a half-width of $10.7 \pm 2.3 \mathrm{~ms}$. The EPSC had a latency of $0.54 \pm 0.22 \mathrm{~ms}(n=11)$ and immediately followed an NBQX-resistant spikelet in 12 of 17 cells (Fig. $5 A, C$ ). With control internal solution, the size of the M-cell EPSC progressively decreased until it disappeared (data not shown). This rapid rundown was prevented by the addition of $10 \mathrm{~mm}$ glutamate in the ET-cell internal solution. Loading with glutamate did not significantly change the amplitude of the EPSC (control, $38 \pm 20 \mathrm{pA}$, $n=6$; glutamate, $29 \pm 25 \mathrm{pA}, n=12 ; p=0.4$ ). Importantly, this transmission was unidirectional: APs in M cells never evoked an EPSP in an ET cell $(n=15)$ (Fig. $5 B)$. 

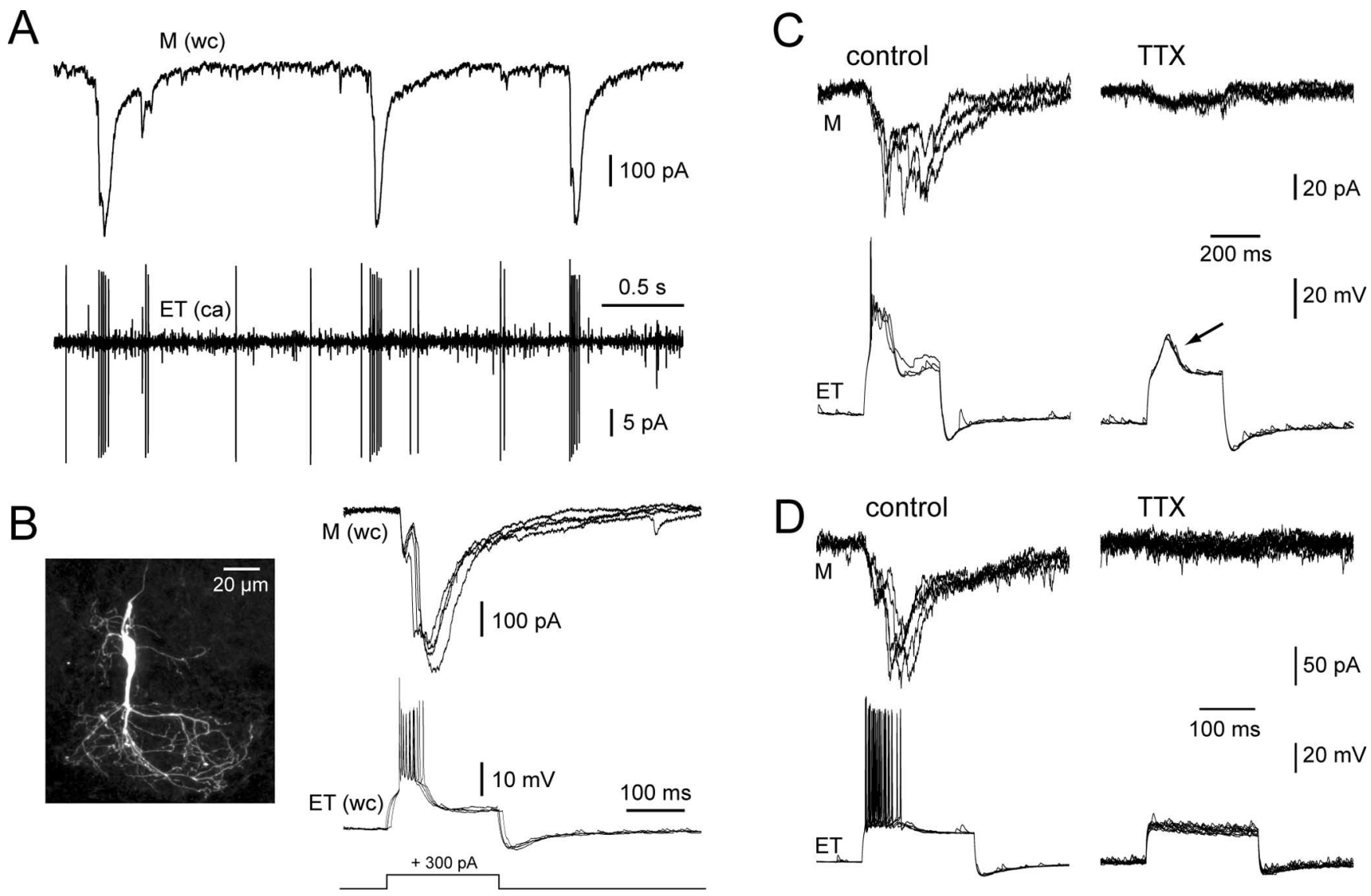

TTX

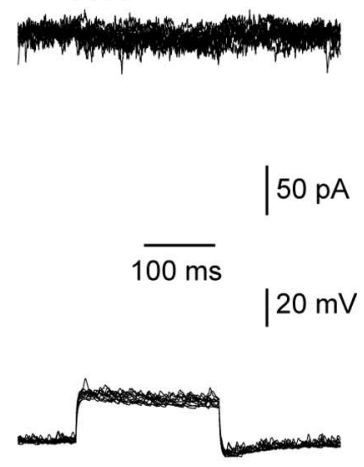

Figure 3. Evoked bursting of a single ET cell induced population burst. $A$, Synchrony between spontaneous population bursts in a M cell (whole-cell configuration, top trace) and bursts of APs in an ET cell (cell-attached configuration, bottom trace). $\boldsymbol{B}$, The ET cell shown in $\boldsymbol{A}$ was then recorded in the whole-cell configuration and filled with biocytin for post hoc visualization (left). Bursts of APs evoked by depolarizing steps ( $300 \mathrm{pA}, 200 \mathrm{~ms}$ ) triggered responses similar to the spontaneous population bursts in the $\mathrm{M}$ cell. Note that the $\mathrm{M}$ cell response started with an EPSC time-locked with the first AP of the ET cell burst. 4 trials are superimposed and aligned on the first AP. C, D, Evoked population bursts in M cells (left panels) were abolished by TTX (1 $\mu \mathrm{M}$, right) whether the ET cell expressed (C) or not (D) a TTX-insensitive $\mathrm{Ca}^{2+}$ spike (arrow). ca, Cell attached; wc, whole cell.
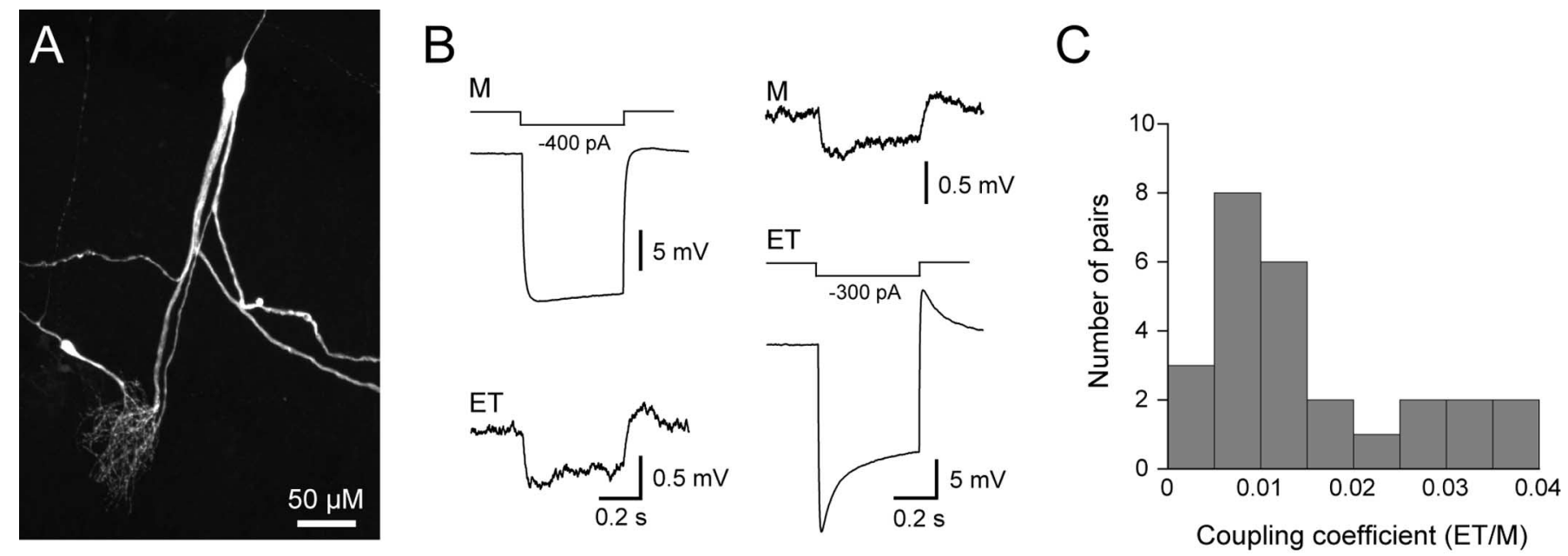

Figure 4. Electrical coupling between mitral and ET cells projecting to the same glomerulus. $A$, Biocytin-filled pair of an $M$ and an ET cell affiliated to the same glomerulus. $B$, In the pair shown in $A$, a hyperpolarizing current injection ( $-400 \mathrm{pA}, 500 \mathrm{~ms}$, top left) in the $\mathrm{M}$ cell induced a small voltage deflection in the ET cell (bottom left). Similarly, a hyperpolarizing current injected in the ET cell ( $-300 \mathrm{pA}, 500 \mathrm{~ms}$, bottom right) caused a small voltage drop in the M cell (top right). C, Summary histogram showing the electrical coupling between ET and M cells in 26 pairs. The coupling coefficient was calculated as the ratio of the voltage deflection in the tested $M$ cell versus stimulated ET cell.

Consistent with previous results in ET cells (Ma and Lowe, 2007), APs also induced an AMPA receptor-mediated autoexcitation that caused a voltage rebound that followed the spike (Fig. $5 C$ ). The rebound depolarization was blocked by NBQX, thus allowing the isolation of the autoexcitatory potential (amplitude, $8.5 \pm 4.5 \mathrm{mV}$; half-width, $9.8 \pm 3.4 \mathrm{~ms} ; n=11$ ) by a substraction protocol (Fig. 5C). The presynaptic autoexcitation and the postsynaptic EPSCs had similar kinetics and paired-pulse depres- 
sion (Fig. 5C). Moreover, the rundown of the M-cell EPSC occurred in parallel with a progressive decrease of autoexcitation. It is thus possible that, similar to the electrochemical mechanism proposed to underlie the synaptic-like transmission between $\mathrm{M}$ cells (Schoppa and Westbrook, 2002; Christie et al., 2005), electrical coupling of the autoreceptor potential mediates the $\mathrm{M}$-cell response rather than conventional synaptic transmission (but see Pimentel and Margrie, 2008).

Excitatory transmission between ET and $M$ cell pairs was robust (no failures) but transient, consistent with the strong paired-pulse depression (Fig. 5C). For example, when autoexcitation in an ET cell triggered a second AP, this second spike did not evoke an EPSC in the M cell (Fig. $5 D)$. Similarly, during longer trains of APs, only the first reliably triggered an EPSC (Fig. 5E). Because sodium-dependent APs seem to be the triggering signal for dendritic release of glutamate from ET cells (Fig. 3C), evoked synaptic transmission appears limited to the first stimulus in a spike train.

\section{Do external tufted cells mediate}

\section{feedforward excitation of mitral cells?} Stimulation of the OSN evokes EPSPs in M cells that have a time course similar to the spontaneous population bursts (Carlson et al., 2000; De Saint Jan and Westbrook, 2007). Thus, we tested whether ET-cell activity contributes to sensory neuronevoked $\mathrm{M}$ cell responses. In cell-attached recording, low-intensity stimulation of the olfactory nerve layer evoked bursts of APs in the majority of ET cells (12 of 13) (Fig. $6 A$ ). The minimal stimulus that evoked a burst of APs in cell-attached recording was nearly the same ( $30 \pm 10 \mu \mathrm{A} ; n=6)$ as the threshold intensity that evoked EPSCs in whole-cell recording $(24 \pm 11 \mu \mathrm{A} ; n=6$; data not shown). Thus, even weak inputs produce bursts of APs in ET cells.

We compared OSN-evoked firing patterns in ET and M cells in seven cell pairs. In four pairs, minimal stimulations evoked burst of APs in the ET cell, whereas the $M$ cell was silent. Stronger stimuli induced firing of both cells. In the other three pairs, both cells fired at any stimulus strength. When both cells were activated, the $M$ cell always fired with a longer and more variable latency than the ET cell (Fig. $6 A-C$ ). Increasing the stimulation intensity progressively decreased the latency of the first AP for both cells (Fig. 6B).

In whole-cell recordings, a weak stimulation produced small all-or-none, slow rising and long-lasting EPSPs in M cells $(n=7)$ (Fig. $7 A, B)$. These responses were blocked by $\operatorname{NBQX}(n=4$; data not shown), although their time course was not consistent with a
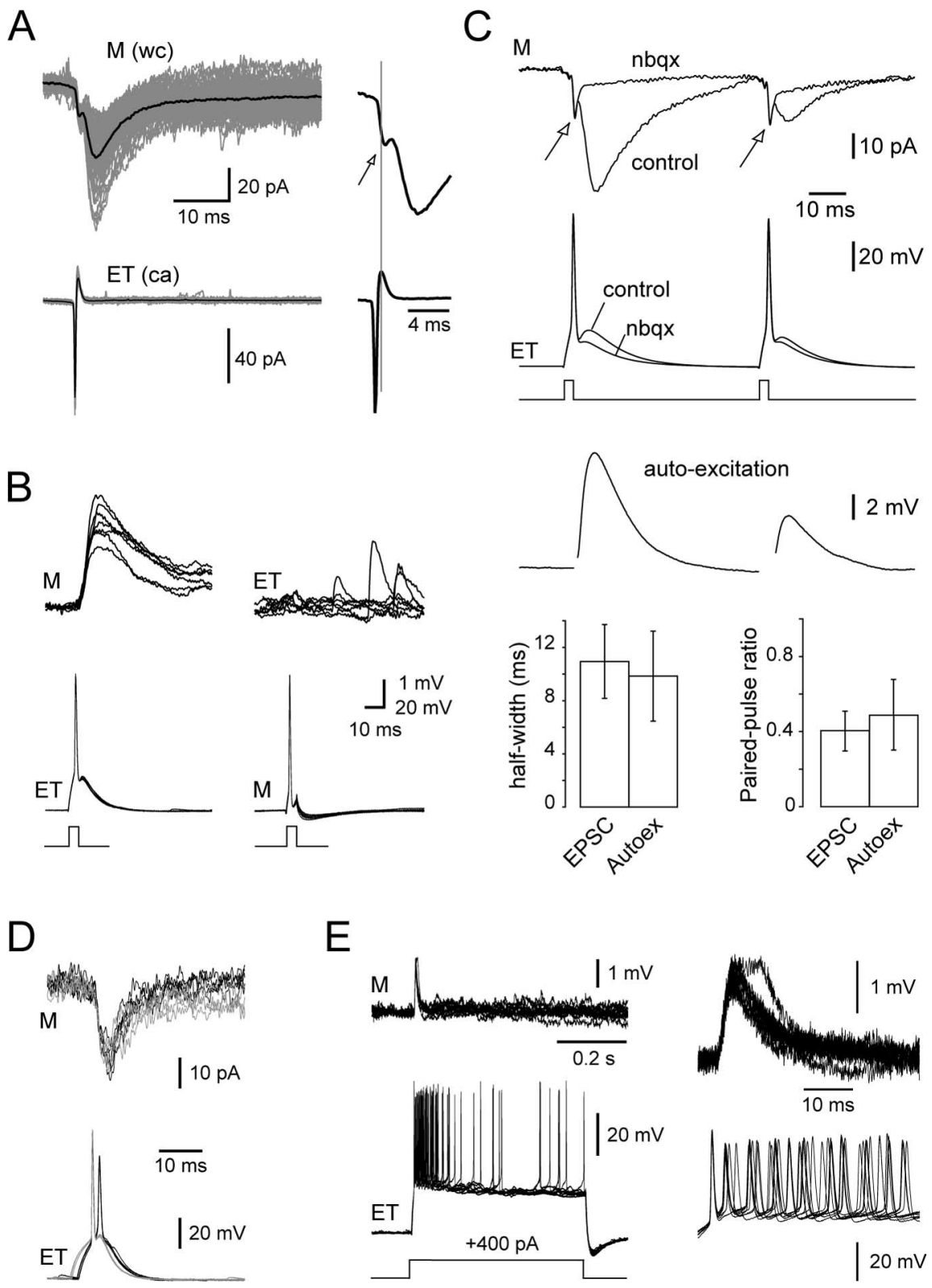

Figure 5. Unidirectional synaptic-like excitatory transmission between ET and mitral cells. $A$, Spontaneous APs recorded in an ET cell ( $n=158$, cell attached, bottom) were coincident with EPSCs in an M cell projecting to the same glomerulus. Average traces (black) are superimposed on raw traces (gray). Right, Expanded average traces. Note the spikelet (arrow) locked to the spike in the M-cell response. $\boldsymbol{B}$, Individual APs evoked by short depolarizing steps ( $4 \mathrm{~ms}, 600 \mathrm{pA}$ ) in the ET cell (left) elicited EPSPs in an M cell, whereas APs in the M cell (5 $\mathrm{ms}, 1.3 \mathrm{nA}$ ) did not (right). Six trials are superimposed. C, Two APs evoked ( $2 \mathrm{~ms}, 800 \mathrm{pA}$ ) at $50 \mathrm{~ms}$ interval in the ET cell produced EPSCs in the M cell (top) and autoexcitatory potentials in the stimulated cell (bottom). Both responses were blocked by NBQX (10 $\mu \mathrm{m}$ ) and strongly depressed. The spikelet preceding the M-cell response (arrows) was not affected by NBQX. Autoexcitatory potentials were obtained by substracting the AP in NBQX from the control trace. Traces are average of 37 trials. Bottom, Summary graph showing the paired-pulse ratio (interstimulus interval of $50 \mathrm{~ms}$ ) and half-width of M-cell EPSCs $(n=11)$ and ET-cell autoexcitatory potentials $(n=10)$. D, Secondary APs induced by rebound autoexcitatory potentials in ET cells did not evoke additional EPSCs in M cells. Nine EPSCs are superimposed, four induced by single AP (gray) and five evoked by doublets of APs (black). Traces are aligned on the firstET-cell AP.E, Only the first AP of a burst in an ET cell consistently triggered an EPSP in an M cell. Ten traces aligned on the first AP are superimposed. Right, Same traces on a larger timescale. ca, Cell attached; wc, whole cell.

monosynaptic AMPA receptor-mediated EPSP. In contrast, the simultaneously recorded NBQX-sensitive ET-cell response was much larger (Fig. $7 E$ ) and had the typical fast time course of a monosynaptic EPSP (Fig. 7C,E). A weak stimulus that failed to evoke a response in one cell also failed to evoke a response in the other cell, suggesting that OSN-evoked responses in $\mathrm{M}$ and ET cells were linked. The rising phase of the $\mathrm{M}$-cell response at threshold was sometimes biphasic $(n=4)$ (Fig. $7 B)$, consisting of 

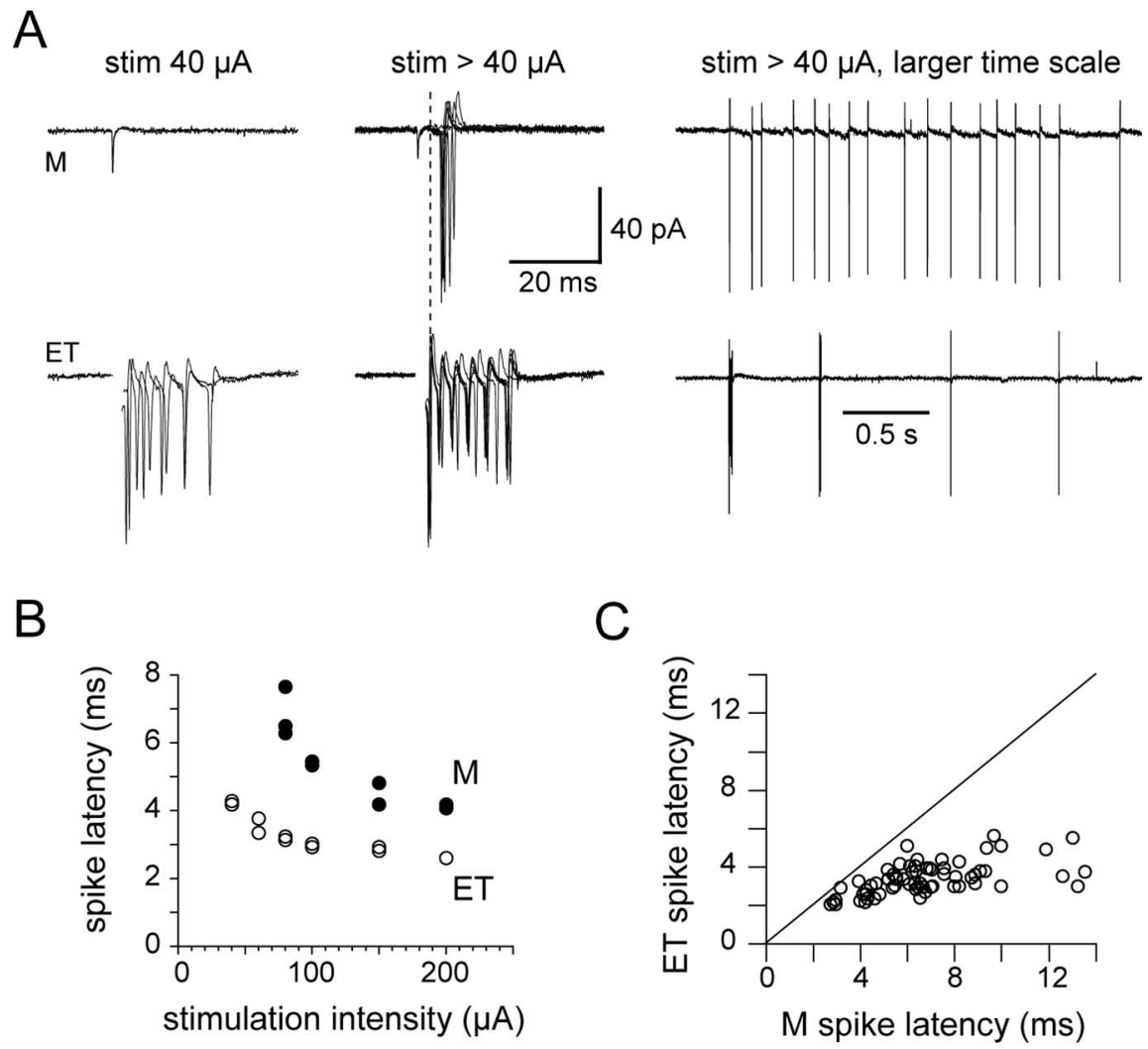

Figure 6. The threshold for OSN-evoked firing is lower for ET cells than for mitral cells. A, OSN-evoked responses in a pair M/ET (cell-attached recordings). At a weak intensity of stimulation ( $40 \mu \mathrm{A}$, left, 2 sweeps superimposed), the ET responded with a burst of APs, whereas the M cell was silent. At higher intensities of stimulation (middle traces, stimulation $>40 \mu \mathrm{A}, 6$ sweeps superimposed), the two cells fired APs. Note that the first spikes in the M cell occurred with a longer latency than the first spike of the ET cell burst. The stimulus artifact has been digitally blanked in the ET response. Right trace, A single response evoked by a stimulation $>40 \mu$ A is shown with a longer timescale. Note the different pattern of discharge. $\boldsymbol{B}$, Spike latency versus stimulation intensity for another pair. The latency was measured between the beginning of the stimulus artifact and the positive peak of the first spike recorded in cell attached. Note that, at two intensities ( 40 and $60 \mu \mathrm{A}$ ), only the ET responded. Two to three sweeps were recorded at each intensity. $C$, Compared spike latency in ET and $M$ cells at variable intensity of stimulation for all the pairs examined $(n=7)$.

a small, rapid initial component that was simultaneous with the ET-cell EPSP (Fig. 7C). This fast component likely reflects a monosynaptic input from the olfactory nerve afferents. However, the overall M-cell EPSP resembled the spontaneous population bursts (Fig. 7D). The rise time of the M-cell response progressively became faster with increases in stimulus strength and was as fast as the ET-cell EPSP with strong stimulation (Fig. 7C,E). Thus, our results are consistent with a scenario in which ET cells activated by a weak sensory input trigger activity in the glomerular network and the slow EPSP of M cells.

\section{Discussion}

\section{External tufted cells and olfactory bulb glomeruli}

A significant role for ET cells in glomerular processing of olfactory inputs has been discussed only recently (Hayar et al., 2004a,b, 2005; Liu and Shipley, 2008). These studies demonstrate that the intrinsic membrane properties of ET cells underlie rhythmic bursts of APs, which are synchronized in ET cells connected to the same glomerulus. They also suggest that ET cells principally drive inhibitory neurons of the glomerular circuit. Thus, it has been hypothesized that ET cells coordinate activity within a glomerulus (Wachowiak and Shipley, 2006).

Our data suggest that ET cells also drive the rhythmic activity of the M-cell assembly. Several observations support this idea.
Slow glomerulus-specific population bursts, which reflect a synchronized activation of the network, depend on glutamate-mediated transmission (Isaacson, 1999; Carlson et al., 2000; Puopolo and Belluzzi, 2001; Schoppa and Westbrook, 2001; Christie et al., 2005; De Saint Jan and Westbrook, 2007). The pacemaker properties of ET cells result in bursts of APs in synchrony with population bursts in the M-cell ensemble. Importantly, ET cells can activate $M$ cells through excitatory connections, but perhaps most convincing is our observation that individual ET cells can drive population bursts in M-cell ensembles. Our cell-attached recordings as well as the $\mathrm{Ca}^{2+}$ imaging experiments in GCaMP-2 mice further suggest that coordinated activity of this network causes synchronized firing of a large ensemble of $\mathrm{M}$ and ET cells. Therefore, the recruitment of multiple ET cells by odorant stimuli would be expected to provide even stronger excitatory drive to the glomerular network.

Under the conditions of our experiments, ET cells fired earlier than M cells in response to afferent stimulation, suggesting that ET cells mediate feedforward excitation of $\mathrm{M}$ cells. This is consistent with in vivo recordings showing that ET cells respond to odors at the onset of inhalation and earlier than $\mathrm{M}$ cells (Buonviso et al., 2003). Sensory inputs could evoke discharge in several ET cells and subsequent population bursts in M cells. Our data also suggest that this feedforward excitation predominates for weak inputs and complements the direct monosynaptic EPSP when the strength of the input increases. This mechanism would be expected to amplify weak inputs and ensure synchronous activation of $\mathrm{M}$ cells within a glomerulus. Although M cells are often considered as the principal targets of olfactory receptor neurons, weak afferent stimulation seemed to preferentially activate ET cells. The higher input resistance of ET cells and their repertoire of voltage-activated channels that promotes hyperexcitability (Hayar et al., 2004b; Liu and Shipley, 2008) may in part explain this property. Olfactory receptor neurons could also form more synapses onto ET cells than onto $\mathrm{M}$ cells, but anatomical evidence is so far lacking because it has not been possible to distinguish M-cell from ET-cell dendrites in EM studies (Wachowiak and Shipley, 2006). Alternatively, different populations of sensory neurons could innervate $\mathrm{M}$ and ET cells.

\section{Electrochemical connections between ET and M cells}

ET and M cells are electrically coupled through gap junctions. Our results thus put a name on the previously unidentified juxtaglomerular cell type that forms gap junctions with M-cell dendrites (Kosaka and Kosaka, 2005). Coupling coefficients for ET-M cell pairs were small $(\sim 1.4 \%)$ compared with the values reported previously for M-cell pairs $(\sim 4 \%)$ (Schoppa and Westbrook, 2002; Christie et al., 2005) or between neurons in other brain regions (Bennett and Zukin, 2004). However, every ET-M 
pair within the same glomerulus was electrically coupled. This suggests that each ET cell is connected to the gap junctional network within a glomerulus. Because ET-cell $\mathrm{Ca}^{2+}$ spikes are large and slow events, they may be efficiently transmitted through this gap junctional network (Bennett and Zukin, 2004).

Surprisingly, ET cells activated EPSPlike depolarizations in $\mathrm{M}$ cells. Transmission between ET and M cells was highly reliable but limited to a single fast EPSP. The EPSPs between ET and M cells were unidirectional, whereas the electrical coupling between ET and M cells was reciprocal, as expected for electrical synapses. Thus, M-cell EPSPs appear independent of electrical coupling through gap junctions. This suggests that conventional chemical synapses underlie this transmission, although dendrodendritic excitatory synapses have not been reported in ultrastructural studies (Pimentel and Margrie, 2008). Alternatively, these EPSPs may reflect a mixed electrochemical response in which AMPA-mediated autoexcitatory potentials in an ET cell are electrically transmitted to an $\mathrm{M}$ cell, as hypothesized for $M$ cells by Schoppa and Westbrook (2002). Consistent with the latter hypothesis, we were unable to reliably alter the amplitude of ET-cell-evoked EPSCs by changing the holding potential of an $\mathrm{M}$ cell (data not shown). However, fast evoked EPSCs generated in distal dendrites are difficult to voltage clamp in large neurons such as M cells.
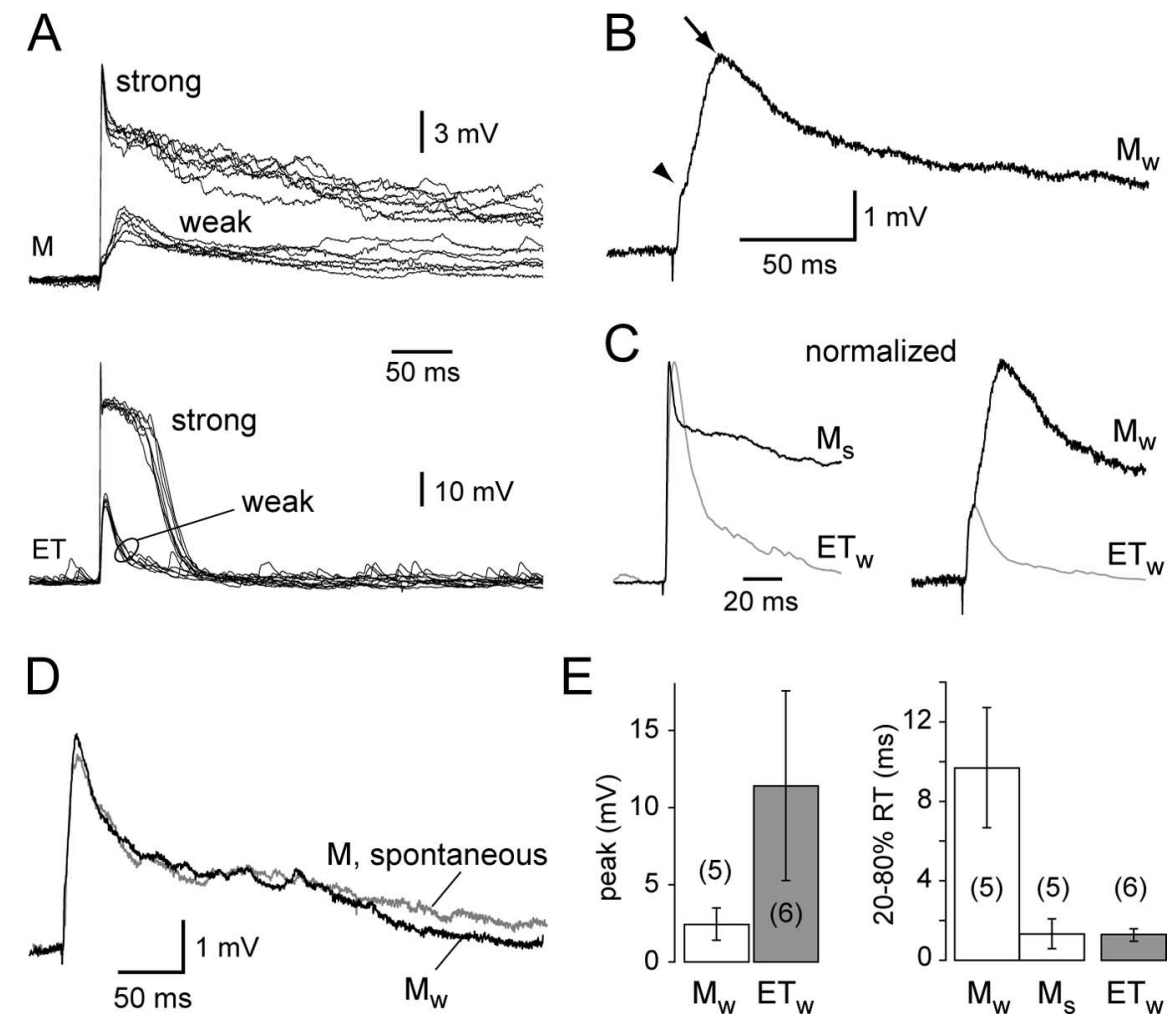

Figure 7. Feedforward activated population bursts mediate the OSN-evoked mitral cell response. $\boldsymbol{A}$, Evoked whole-cell EPSPs recorded simultaneously in an $\mathrm{M}$ and an $\mathrm{ET}$ cell in response to strong (7 traces) or weak (6 traces) stimulation of the olfactory nerves. $\boldsymbol{B}$, Averaged $M$-cell response to weak stimuli $\left(M_{w}\right)$. The rising phase was biphasic with a rapid (arrowhead) and slow (arrow) component. $C$, The M-cell response evoked by a strong shock ( $M_{s^{\prime}}$ left, black trace) had a fast rise time similar to the ET-cell EPSP evoked by weak stimuli ( $\mathrm{ET}_{\text {w, }}$ gray trace) and consistent with a monosynaptic response. The fast component of the M-cell response produced by weak inputs (right, $M_{w}$ ) and the ET-cell EPSPs were simultaneous and had similar rise time. Traces have been normalized for comparison. $\boldsymbol{D}$, The average M-cell response evoked by a weak input (black trace) had a slow time course similar to the population burst (gray trace) averaged from five spontaneous events that occurred during the course of this experiment. Traces are not normalized here. $\boldsymbol{E}$, Graph comparing peak amplitudes of M-cell (white bar) and ET-cell (gray bar) responses to weak stimulation of the sensory afferents (left) and rise time of EPSPs evoked by strong (s) or weak (w) stimulation on the right.

\section{Generating slow oscillations}

In olfactory bulb slices, synchronized rhythmic activity occurs in $\mathrm{M}$ cells projecting to the same glomerulus. This activity can be induced by electrical stimulation of the olfactory afferents (Schoppa and Westbrook, 2001) or manipulations that increase excitability (Isaacson, 1999; Carlson et al., 2000; Puopolo and Belluzzi, 2001; Schoppa and Westbrook, 2001; Christie et al., 2005). The reported frequency $(0.04-2 \mathrm{~Hz})$ and time course of this activity varies, but there is consensus that the rhythmic activity is generated within glomeruli by glutamatergic inputs. This activity likely develops from several rather than unique components of the glomerular network. Glomerulus-specific excitatory connections exist between $\mathrm{M}$ cells (Schoppa and Westbrook, 2002; Urban and Sakmann, 2002; Christie et al., 2005; Pimentel and Margrie, 2008) and, as we show, between ET and M cells. Action potentials in these cells induce dendritic release of glutamate and autoexcitation (Aroniadou-Anderjaska et al., 1999; Isaacson, 1999; Friedman and Strowbridge, 2000; Salin et al., 2001; Schoppa and Westbrook, 2001, 2002; Ma and Lowe, 2007). Asynchronous afferent activity leading to action potentials in ET or $M$ cells could spread through the coupled network and thus increase excitability in the period that leads up to population bursts in M and ET cells. This scenario would be similar to synchronous population bursts in epileptic hippocampus (de la Prida et al., 2006).
The connexin forming gap junctions between ET and M cells and between ET cells could be connexin 36 or perhaps connexin 45 , which is also expressed in olfactory bulb glomeruli (Zhang and Restrepo, 2002; Rash et al., 2005). However, synchronized oscillations persist in connexin 36 knock-out mice, albeit only with stronger stimulation (Christie et al., 2005). Thus, electrical coupling appears not to be an absolute requirement for rhythmic activity. Thus, it may be that direct chemical synapses between ET and $M$ cells and between $M$ cells are sufficient to generate synchronized oscillations at least at low frequencies. The strong paired-pulse depression of these connections would not support high-frequency oscillations.

\section{External tufted cells in odor coding}

In vivo, odors evoke slow rhythmic activity that is synchronized with respiration (Macrides and Chorover, 1972; Chaput et al., 1992; Charpak et al., 2001; Cang and Isaacson, 2003). This activity persists, although not as regular, in the absence of odorant input (Fontanini et al., 2003) and can be uncoupled from the breathing cycle in mice lacking mechanosensitive olfactory receptors (Grosmaitre et al., 2007). Furthermore, glomerular networks in vitro can oscillate in the same frequency range as breathing frequencies (Schoppa and Westbrook, 2001), suggesting that intrinsic properties of the glomerular circuit are primed to gen- 
erate slow rhythmic activity. Our results support this hypothesis and assign a major role to ET cells, whose pacemaker activity can be entrained by afferent inputs (Hayar et al., 2004b). Thus, periodic sensory inputs could impose the breathing frequency on ET-cell bursting that in turn could entrain the activity of the glomerular network. Large-amplitude depolarizations in phase with the input rhythm improve the gain of the postsynaptic response and amplify the response of $\mathrm{M}$ cells to sensory input.

Odor perception is a fast process $(<200 \mathrm{~ms}$ ) (Uchida and Mainen, 2003; Abraham et al., 2004; Rinberg et al., 2006; Wesson et al., 2008). It has thus been proposed that odor identity and intensity can be encoded by spike onset latencies in bulb output neurons (Schaefer and Margrie, 2007; Wesson et al., 2008). This rapid processing would represent the relative timing of response in odor-specific combinations of glomeruli. Could ET cells participate in this encoding mechanism? ET cells appear to be a major target of olfactory receptor neurons and responded to weak stimuli that do not activate $M$ cells. Thus, although the projection of their axons is not known (Wachowiak and Shipley, 2006), ET cells could also serve as an output signaling pathway that is independent of mitral cells.

\section{References}

Abraham NM, Spors H, Carleton A, Margrie TW, Kuner T, Schaefer AT (2004) Maintaining accuracy at the expense of speed: stimulus similarity defines odor discrimination time in mice. Neuron 44:865-876.

Antal M, Eyre M, Finklea B, Nusser Z (2006) External tufted cells in the main olfactory bulb form two distinct subpopulations. Eur J Neurosci 24:1124-1136.

Aroniadou-Anderjaska V, Ennis M, Shipley MT (1999) Dendrodendritic recurrent excitation in mitral cells of the rat olfactory bulb. J Neurophysiol 82:489-494.

Aroniadou-Anderjaska V, Zhou FM, Priest CA, Ennis M, Shipley MT (2000) Tonic and synaptically evoked presynaptic inhibition of sensory input to the rat olfactory bulb via GABA(B) heteroreceptors. J Neurophysiol 84:1194-1203.

Aungst JL, Heyward PM, Puche AC, Karnup SV, Hayar A, Szabo G, Shipley MT (2003) Centre-surround inhibition among olfactory bulb glomeruli. Nature 426:623-629.

Bennett MV, Zukin RS (2004) Electrical coupling and neuronal synchronization in the mammalian brain. Neuron 41:495-511.

Buonviso N, Chaput MA, Berthommier F (1992) Temporal pattern analyses in pairs of neighboring mitral cells. J Neurophysiol 68:417-424.

Buonviso N, Amat C, Litaudon P, Roux S, Royet JP, Farget V, Sicard G (2003) Rhythm sequence through the olfactory bulb layers during the time window of a respiratory cycle. Eur J Neurosci 17:1811-1819.

Buonviso N, Amat C, Litaudon P (2006) Respiratory modulation of olfactory neurons in the rodent brain. Chem Senses 31:145-154.

Cang J, Isaacson JS (2003) In vivo whole-cell recording of odor-evoked synaptic transmission in the rat olfactory bulb. J Neurosci 23:4108-4116.

Carlson GC, Shipley MT, Keller A (2000) Long-lasting depolarizations in mitral cells of the rat olfactory bulb. J Neurosci 20:2011-2021.

Chaigneau E, Tiret P, Lecoq J, Ducros M, Knöpfel T, Charpak S (2007) The relationship between blood flow and neuronal activity in the rodent olfactory bulb. J Neurosci 27:6452-6460.

Chaput MA, Buonviso N, Berthommier F (1992) Temporal patterns in spontaneous and odour-evoked mitral cell discharges recorded in anaesthetized freely breathing animals. Eur J Neurosci 4:813-822.

Charpak S, Mertz J, Beaurepaire E, Moreaux L, Delaney K (2001) Odorevoked calcium signals in dendrites of rat mitral cells. Proc Natl Acad Sci U S A 98:1230-1234.

Christie JM, Bark C, Hormuzdi SG, Helbig I, Monyer H, Westbrook GL (2005) Connexin 36 mediates spike synchrony in olfactory bulb glomeruli. Neuron 46:761-772.

Debarbieux F, Audinat E, Charpak S (2003) Action potential propagation in dendrites of rat mitral cells in vivo. J Neurosci 23:5553-5560.

de la Prida LM, Huberfeld G, Cohen I, Miles R (2006) Threshold behavior in the initiation of hippocampal population bursts. Neuron 49:131-142.
De Saint Jan D, Westbrook GL (2007) Disynaptic amplification of metabotropic glutamate receptor 1 responses in the olfactory bulb. J Neurosci 27:132-140.

Díez-García J, Matsushita S, Mutoh H, Nakai J, Ohkura M, Yokoyama J, Dimitrov D, Knöpfel T (2005) Activation of cerebellar parallel fibers monitored in transgenic mice expressing a fluorescent $\mathrm{Ca}^{2+}$ indicator protein. Eur J Neurosci 22:627-635.

Ennis M, Zhou FM, Ciombor KJ, Aroniadou-Anderjaska V, Hayar A, Borrelli E, Zimmer LA, Margolis F, Shipley MT (2001) Dopamine D2 receptormediated presynaptic inhibition of olfactory nerve terminals. J Neurophysiol 86:2986-2997.

Fontanini A, Spano P, Bower JM (2003) Ketamine-xylazine-induced slow $(<1.5 \mathrm{~Hz})$ oscillations in the rat piriform (olfactory) cortex are functionally correlated with respiration. J Neurosci 23:7993-8001.

Friedman D, Strowbridge BW (2000) Functional role of NMDA autoreceptors in olfactory mitral cells. J Neurophysiol 84:39-50.

Grosmaitre X, Santarelli LC, Tan J, Luo M, Ma M (2007) Dual functions of mammalian olfactory sensory neurons as odor detectors and mechanical sensors. Nat Neurosci 10:348-354.

Hayar A, Karnup S, Ennis M, Shipley MT (2004a) External tufted cells: a major excitatory element that coordinates glomerular activity. J Neurosci 24:6676-6685.

Hayar A, Karnup S, Shipley MT, Ennis M (2004b) Olfactory bulb glomeruli: external tufted cells intrinsically burst at theta frequency and are entrained by patterned olfactory input. J Neurosci 24:1190-1199.

Hayar A, Shipley MT, Ennis M (2005) Olfactory bulb external tufted cells are synchronized by multiple intraglomerular mechanisms. J Neurosci 25:8197-8208.

Isaacson JS (1999) Glutamate spillover mediates excitatory transmission in the rat olfactory bulb. Neuron 23:377-384.

Kosaka T, Kosaka K (2005) Intraglomerular dendritic link connected by gap junctions and chemical synapses in the mouse main olfactory bulb: electron microscopic serial section analyses. Neuroscience 131:611-625.

Liu S, Shipley MT (2008) Multiple conductances cooperatively regulate spontaneous bursting in mouse olfactory bulb external tufted cells. J Neurosci 28:1625-1639.

Ma J, Lowe G (2007) Calcium permeable AMPA receptors and autoreceptors in external tufted cells of rat olfactory bulb. Neuroscience 144:1094-1108.

Macrides F, Chorover SL (1972) Olfactory bulb units: activity correlated with inhalation cycles and odor quality. Science 175:84-87.

McQuiston AR, Katz LC (2001) Electrophysiology of interneurons in the glomerular layer of the rat olfactory bulb. J Neurophysiol 86:1899-1907.

Metzger F, Repunte-Canonigo V, Matsushita S, Akemann W, Diez-Garcia J, Ho CS, Iwasato T, Grandes P, Itohara S, Joho RH, Knöpfel T (2002) Transgenic mice expressing a $\mathrm{pH}$ and $\mathrm{Cl}^{-}$sensing yellow-fluorescent protein under the control of a potassium channel promoter. Eur J Neurosci 15:40-50.

Miles R, Wong RK (1983) Single neurones can initiate synchronized population discharge in the hippocampus. Nature 306:371-373.

Murphy GJ, Darcy DP, Isaacson JS (2005) Intraglomerular inhibition: signaling mechanisms of an olfactory microcircuit. Nat Neurosci 8:354-364.

Pimentel DO, Margrie TW (2008) Glutamatergic transmission and plasticity between olfactory bulb mitral cells. J Physiol 586:2107-2119.

Puopolo M, Belluzzi O (2001) NMDA-dependent, network-driven oscillatory activity induced by bicuculline or removal of $\mathrm{Mg}^{2+}$ in rat olfactory bulb neurons. Eur J Neurosci 13:92-102.

Rash JE, Davidson KG, Kamasawa N, Yasumura T, Kamasawa M, Zhang C, Michaels R, Restrepo D, Ottersen OP, Olson CO, Nagy JI (2005) Ultrastructural localization of connexins ( $\mathrm{Cx} 36, \mathrm{Cx} 43, \mathrm{Cx} 45)$, glutamate receptors and aquaporin- 4 in rodent olfactory mucosa, olfactory nerve and olfactory bulb. J Neurocytol 34:307-341.

Rinberg D, Koulakov A, Gelperin A (2006) Speed-accuracy tradeoff in olfaction. Neuron 51:351-358.

Salin PA, Lledo PM, Vincent JD, Charpak S (2001) Dendritic glutamate autoreceptors modulate signal processing in rat mitral cells. J Neurophysiol 85:1275-1282.

Schaefer AT, Margrie TW (2007) Spatiotemporal representations in the olfactory system. Trends Neurosci 30:92-100. 
Schoppa NE, Westbrook GL (2001) Glomerulus-specific synchronization of mitral cells in the olfactory bulb. Neuron 31:639-651.

Schoppa NE, Westbrook GL (2002) AMPA autoreceptors drive correlated spiking in olfactory bulb glomeruli. Nat Neurosci 5:1194-1202.

Sobel EC, Tank DW (1993) Timing of odor stimulation does not alter patterning of olfactory bulb unit activity in freely breathing rats. J Neurophysiol 69:1331-1337.

Uchida N, Mainen ZF (2003) Speed and accuracy of olfactory discrimination in the rat. Nat Neurosci 6:1224-1229.

Urban NN, Sakmann B (2002) Reciprocal intraglomerular excitation and intra- and interglomerular lateral inhibition between mouse olfactory bulb mitral cells. J Physiol 542:355-367.
Wachowiak M, Shipley MT (2006) Coding and synaptic processing of sensory information in the glomerular layer of the olfactory bulb. Semin Cell Dev Biol 17:411-423.

Wesson DW, Carey RM, Verhagen JV, Wachowiak M (2008) Rapid encoding and perception of novel odors in the rat. PLoS Biol 6:e82.

Wilson RI, Mainen ZF (2006) Early events in olfactory processing. Annu Rev Neurosci 29:163-201.

Zhang C, Restrepo D (2002) Expression of connexin 45 in the olfactory system. Brain Res 929:37-47.

Zhou Z, Xiong W, Masurkar AV, Chen WR, Shepherd GM (2006) Dendritic calcium plateau potentials modulate input-output properties of juxtaglomerular cells in the rat olfactory bulb. J Neurophysiol 96:2354-2363. 